\title{
HSF1 promotes endometriosis development and glycolysis by up-regulating PFKFB3 expression
}

\author{
Yixin Wang, Jing Xiu, Tingting Yang, Chune Ren ${ }^{*}$ and Zhenhai Yu* (D)
}

\begin{abstract}
Background: Endometriosis is a chronic hormonal inflammatory disease characterized by the presence of endometrial tissue outside the uterus. Endometriosis often causes infertility, which brings physical and mental pain to patients and their families.

Methods: We examined the functions of heat shock factor 1 (HSF1) in endometriosis development through cell count assay, cell-scratch assay and clone formation experiments. We used quantitative real-time PCR (qRT-PCR) and Western blot (WB) to detect HSF1 expression. Glucose and lactate levels were determined using a glucose (GO) assay kit and a lactate assay kit. Furthermore, we used a HSF1 inhibitor-KRIBB11 to establish a mouse model of endometriosis.

Results: Our data demonstrated that HSF1 promoted endometriosis development. Interestingly, HSF1 enhanced glycolysis via up-regulating PFKFB3 expression in endometriosis cells, which was a key glycolysis enzyme. Consistently, the HSF1 inhibitor KRIBB11 could abrogate endometriosis progression in vivo and in vitro.
\end{abstract}

Conclusions: Findings indicate that HSF1 plays an important role in endometriosis development, which might become a new target for the treatment of endometriosis.

Electronic supplementary material: Supplementary data are available.

Keywords: HSF1, PFKFB3, Inhibitor, Glycolysis, Endometriosis

\section{Background}

Endometriosis is a disease with features of chronic inflammation, which is defined as the functional endometrial stroma and glands outside the uterine cavity [1]. The main clinical manifestations of endometriosis are lower abdominal pain, dysmenorrhea, infertility, sexual discomfort, abnormal menstruation, local periodic pain, and bleeding. There are approximately $6-10 \%$ of women of childbearing age suffering from endometriosis in the world, and the infertility rate among them is as high as $50 \%$, seriously affecting the women health [2]. Endometriosis is mainly

\footnotetext{
* Correspondence: chuneren@163.com; tomsyu@163.com Department of Reproductive Medicine, Affiliated Hospital of Weifang Medical University, Weifang, Shandong Province, People's Republic of China
}

affected by estrogen and progesterone, which promote endometrial tissue proliferation, survival, and inflammation [3]. In addition, the development of endometriosis is also related to progesterone resistance [4]. The most common theory of endometriosis is the implantation theory, which may be related to genetic and immune inflammatory factors $[5,6]$. However, there is still no effective drug to treat endometriosis.

In eukaryotes, there are many stressors that can cause protein damage and induce an evolutionally conserved cytoprotective mechanism, the heat shock response (HSR), to maintain protein stability [7]. The heat shock factor 1 (HSF1) plays a central role in refolding or degrading intracellular proteins [8]. HSF1 is a transcription

C C The Author(s). 2021 Open Access This article is licensed under a Creative Commons Attribution 4.0 International License, which permits use, sharing, adaptation, distribution and reproduction in any medium or format, as long as you give appropriate credit to the original author(s) and the source, provide a link to the Creative Commons licence, and indicate if changes were made. The images or other third party material in this article are included in the article's Creative Commons licence, unless indicated otherwise in a credit line to the material. If material is not included in the article's Creative Commons licence and your intended use is not permitted by statutory regulation or exceeds the permitted use, you will need to obtain permission directly from the copyright holder. To view a copy of this licence, visit http://creativecommons.org/licenses/by/4.0/ The Creative Commons Public Domain Dedication waiver (http://creativecommons.org/publicdomain/zero/1.0/) applies to the data made available in this article, unless otherwise stated in a credit line to the data. 
factor that can respond to endogenous and exogenous cellular stresses by inducing HSP expression, which could facilitate the refolding of misfolded proteins [9]. HSF1 also plays an important role in tumor development, which seriously affects its prognosis [10]. For example, HSF1 is highly expressed in prostate cancer, and plays its functions by increasing expression of its downstream effector HSP27 [11]. Other tumors such as colorectal cancer, breast cancer, oral cancer, and liver cancer also have a high HSF1 expression [7]. Furthermore, HSF1 can improve the tumor microenvironment to promote its survival [12]. Therefore, HSF1 can be used as a new therapeutic target. However, the roles of HSF1 in endometriosis are still largely unknown.

The increases of glucose metabolism are beneficial to the endometriosis development, and abnormal expressions of glycolysis enzymes were detected in the endometriosis cells [13]. Most normal cells mainly rely on the oxidative metabolism to produce energy, but tumor cells still choose to glycolysis pathway even in the sufficient oxygen [14]. The glycolysis pathway could produce energy quickly, which could satisfy the cell rapid proliferation [15]. Lactate produced from glycolysis promotes angiogenesis, cell invasion and immunosuppression, which promotes tumorigenesis [16]. Interestingly, endometriosis cell made a shift from oxidative phosphorylation to aerobic glycolysis, which inhibits the production of reactive oxide species and then activates survival signals [17]. Therefore, glycolysis could be considered as a target for the treatment of endometriosis. In the process of glycolysis, there is a key enzyme named 6Phosphofructo-2-kinase/Fructose-2, 6-Biphosphatase 3 (PFKFB3), which belongs to a family of bio-functional proteins [18]. There are four members of PFKFB family, among which PFKFB3 has the highest catalytic activity in glycolysis [19]. PFKFB3, as a key enzyme of glycolysis, regulates the process of glycolysis and plays an important role in the occurrence and development of many diseases [20, 21]. Therefore, PFKFB3 has become a potential target for drug development [22]. However, the role of PFKFB3 in endometriosis remains unclear.

Endometriosis is a benign disease, but it has some clinical characteristics similar to the tumor, such as implantable, invasive, and distant metastasis. Moreover, HSF1 was previously reported to be overexpressed in endometriosis [23]. Therefore, we hypothesized that HSF1 also regulated the endometriosis development. To test this hypothesis, we manipulated HSF1 expression in endometriosis cells, and used a constructed mouse model. Our data demonstrated that HSF1 promoted endometriosis development via enhancing PFKFB3 expression. Our study provides a new idea for the clinical treatment of endometriosis by targeting HSF1.

\section{Materials and methods}

\section{Cell culture and antibodies}

The endometriotic epithelial cell line (11Z) was established by Professor Anna Strazinski-Powitz [24]. The human endometrial stromal cell line (ESC) was established by Dr. Krikun [25]. All cell lines were cultured in Dulbecco's Modified Eagle Medium/Ham's F-12 50/50 Mix (DMEM/ F-12) supplemented with 10\% FBS (Gibco, Carlsbad, CA, USA) with $100 \mu \mathrm{g} / \mathrm{mL}$ penicilin and $100 \mu \mathrm{g} / \mathrm{mL}$ streptomycin at $37^{\circ} \mathrm{C}$ and $5 \% \mathrm{CO}_{2}$.

Mouse anti- $\beta$-actin (A1978) was from Sigma-Aldrich, and dilution: 1:5000. Mouse anti-HSF1 (sc-17,757) was from Santa Cruz, and dilution: 1:1000. Rabbit antiPFKFB3 (ab181861) was purchase from Abcam, and dilution: 1:2000. KRIBB11 were obtained from Med Chem Express (MCE), $50 \mathrm{mg} / \mathrm{kg}$.

\section{SiRNA and transfection}

The sequence of small interfering (si) RNAs against HSF1 was 5'- GCAGGUUGUUCAUAGUCAGAA-3'. The sequence of Control (Negative Control) was 5'UUCUCCGAACGGUCACGU-3' [26]. The transfection was performed as described previously [27].

\section{Western blot}

The indicated cells were collected and lysed on ice using lysis buffer (Beyotime, Shanghai, China, P0013), and were centrifuged at $12000 \mathrm{rpm}$ at $4{ }^{\circ} \mathrm{C}$ for $15 \mathrm{~min}$. Then, $5 \times$ loading buffer was added to the sample, and boiled for $10 \mathrm{~min}$. The protein was separated by SDS-PAGE and transferred to PVDF membrane. After blocking, immunoblot assay was performed using indicated antibodies, which was performed as described previously [28].

\section{Quantitative real-time PCR}

The isolation of total RNA from cells and the synthesis of cDNA were described above [29]. Quantitative realtime PCR used SYBR Green PCR Master Mix (Takara) with CFX96 Real-Time PCR detection system (Bio-Rad, shanghai, China).

\section{Cell proliferation assay}

The cells were transfected with the indicated plasmids. After $24 \mathrm{~h}$, the transfected cells were reseeded in 24-well plates. The cell numbers were counted every $24 \mathrm{~h}$ for 4 days [28].

\section{Colony-formation assay}

The cells were transfected with indicated plasmids. After $24 \mathrm{~h}, 500$ transfected cells were reseeded in new six-well plates. After cultured for 10-14 days, the cells were fixed with $4 \%$ paraformaldehyde for $15 \mathrm{~min}$. Then, the cells were stained with crystal violet for $20 \mathrm{~min}$, and photographed [30]. 


\section{Cell-scratch assay}

The cells were transfected with indicated plasmids. After $24 \mathrm{~h}$, the transfected cells were reseeded in new 6-well plates. The pipette tip was used to draw a line and washed with PBS. After $24 \mathrm{~h}$, cells were photographed [31].

\section{Glucose consumption and lactate production}

The cells were transfected with indicated plasmids. After $24 \mathrm{~h}$, the transfected cells were reseeded in new 6-well plates. After 1 day, and the culture mediums were collected to determine the concentration of glucose and lactic acid using glucose (GO) assay kit (Sigma, \#GAGO20-1KT) and lactate assay kit (Biovision, \#K627-100). The methods were performed as described previously $[28,30]$.

\section{Animal experiments}

Animal experiments have been approved by ethics Committee of Weifang Medical University. We used 5-weekold BALB/c female mice, and the donor mice $(n=5)$ were injected with estradiol benzoate to promote endometrial development. Estradiol benzoate was diluted with oil and injected intramuscularly into the thigh of donor mice, $3 \mu \mathrm{g} /$ mouse, 2 times for 1 week. After 1 week, the uterus from donor mice was cut into pieces and intraperitoneally injected into the recipient mice. After 1 week, the mice in the experimental group $(n=7)$ were intraperitoneally injected HSF1 inhibitor KRIBB11, and the mice in the control group $(n=7)$ were injected with normal saline, 2 times a week for 1 month. Then, the mice were sacrificed to observe the endometrial lesion.

\section{Tissue collection and immunohistochemistry}

All tissues were obtained from endometriosis mouse model. The sections were embedded in paraffin, dried and dewaxed with xylene, then hydrated in ethanol. Antigen extract was heated in a microwave oven for 30 min, and incubated with $3 \% \mathrm{H}_{2} \mathrm{O}_{2}$ for 20 min to block endogenous peroxidase. Primary antibody was incubated overnight at $4{ }^{\circ} \mathrm{C}$, and secondary antibody was incubated in the next day. After staining with DAB, the nucleus was stained with hematoxylin. Then, it is dehydrated in ethanol and xylene. The immunohistochemistry was performed as described previously [27]. The immunostaining intensity was quantified using the Image J [32].

\section{Statistical analysis}

All statistical analyses were done using Graphpad Prism 5.0 software. The statistical analyses were presented as mean \pm SEM, and performed by two-tailed unpaired Student's t-test. $P$ values $<0.05$ were considered to be statistically significant. n.s. was not significant.

\section{Results}

HSF1 promotes cell proliferation, cell migration and clone formation in endometriosis cells

To determine whether HSF1 plays an important role in endometriosis, we manipulated HSF1 expression in endometriosis cells. We found that HSF1 overexpression significantly promoted cell proliferation in endometriosis cells (Fig. 1A). Moreover, cell-scratch tests and clone formation experiments revealed that HSF1 overexpression promoted cell migration and growth in endometriosis cells (Fig. 1B and C). Conversely, HSF1 knockdown inhibited the growth of endometriosis cells (Fig. 1D and F), and inhibited cell migration (Fig. 1E). These findings suggest that HSF1 positively regulates cell proliferation and migration in endometriosis cells.

\section{HSF1 enhances glycolysis in endometriosis cells}

Endometriosis cells need high glycolysis in the process of rapid metastasis and growth [13]. To determine the functions of HSF1 in glycolysis, we overexpressed or knocked down HSF1 in endometriosis cells. Interestingly, we found that HSF1 could increase both glucose consumption and lactate production (Fig. 2A and B). Subsequently, to determine whether HSF1 inhibitor KRIBB11 could suppress glucose metabolism, we cultured endometriosis cells with KRIBB11. Consistently, KRIBB11 reduced the glucose consumption and lactic acid generation in endometriosis cells (Fig. 2A and B). These data show that HSF1 enhances glycolysis in endometriosis cells.

\section{HSF1 promotes PFKFB3 expression in endometriosis cells}

In the previous experiment of the current study, we showed that HSF1 promotes glycolysis in endometriosis cell. Therefore, we hypothesized that regulation of glycolysis by HSF1 might depend on key glycolytic enzymes. So we selected three key enzymes in glycolysis to verify our hypothesis, PFKFB3, PKM2 and HK2. Exposing cells to heat-shock in a time-dependent manner, the PFKFB3 expression were increased (Fig. 3A and B). But heat-shock activation had little effect on the PKM2 and HK2 expressions (Supplementary Fig. $1 \mathrm{~A}$ and B). In addition, overexpression HSF1 increased PFKFB3 expression (Fig. 3C and D). Conversely, HSF1 knockdown resulted in a decrease in PFKFB3 expression (Fig. 3E and F). Taken together, our results indicate that HSF1 promotes PFKFB3 expression in endometriosis cells.

\section{KRIBB11 inhibits endometriosis cell growth by targeting HSF 1}

KRIBB11, a specific inhibitor of HSF1, effectively inhibits HSF1 activity, leading to cell cycle arrest in the G2/M phase, cell apoptosis, and inhibition of tumor cell proliferation [33]. Cells were seeded in 24-well plates and 


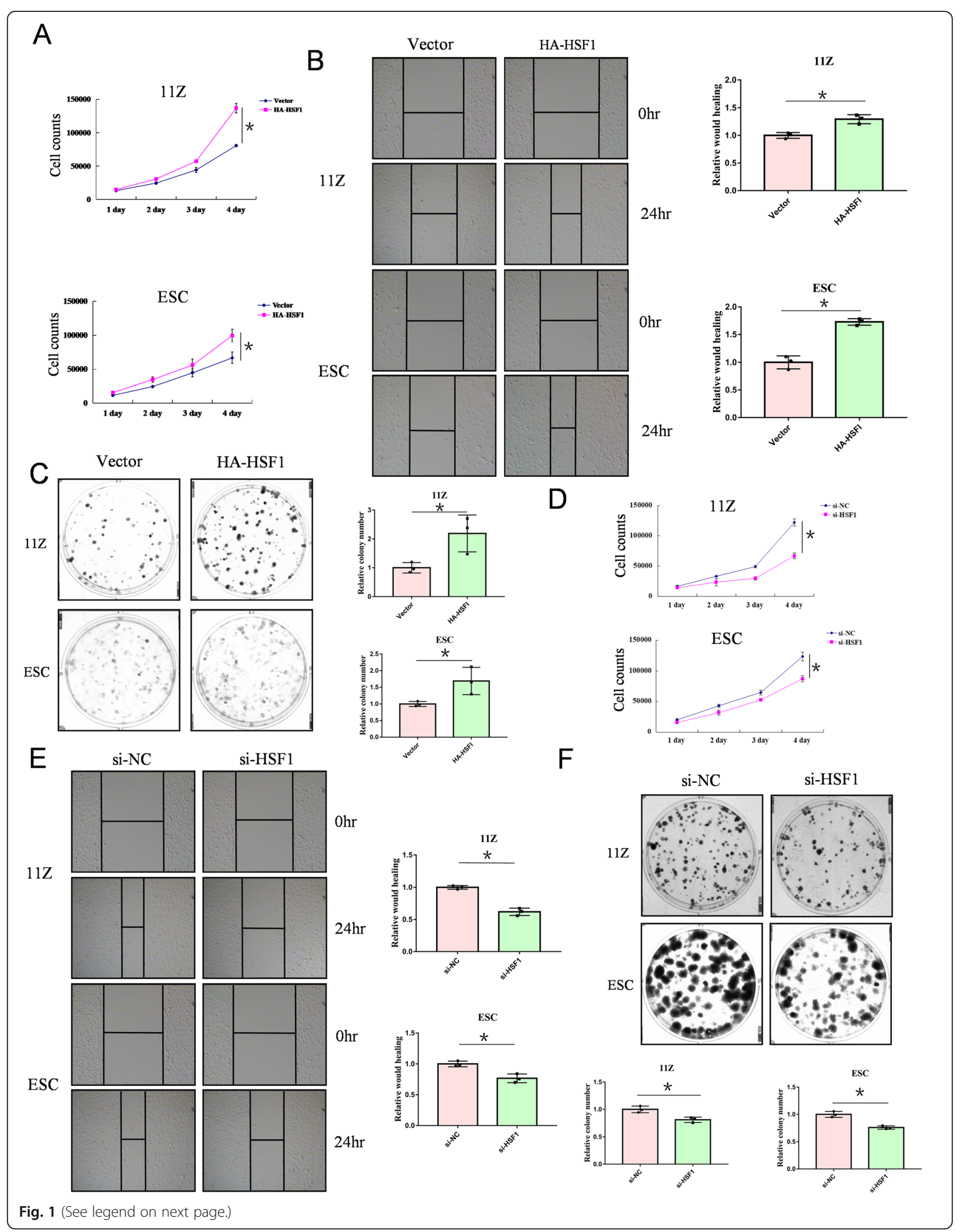


(See figure on previous page.)

Fig. 1 HSF1 promotes the cell proliferation, cell migration and clone formation in endometriosis cells. (A) $11 \mathrm{Z}$ and ESC cells were transfected with HA-tagged HSF1 or empoty vector. After one day, cells were re-plated in 24-well plates, and cell counts were performed every $24 \mathrm{~h}$ to analyses cell growth. (B) $11 Z$ and ESC cells were transfected with HA-tagged HSF1 or empoty vector. After one day, cells were re-plated in 6-well plates to perform scratch test assay. (C) $11 \mathrm{Z}$ and ESC cells were transfected with HA-tagged HSF1 or empoty vector. After one day, cells were re-plated in 6-well plates, and were cultured for 10-14 days to observe the cell clone formation. (D-F) 11 Z and ESC cells were transfected with siRNA-HSF1 or NC. Cell counting, scratching, and cloning were performed. All date are mean \pm SD of three independent experiments $\left({ }^{*} P<0.05\right)$

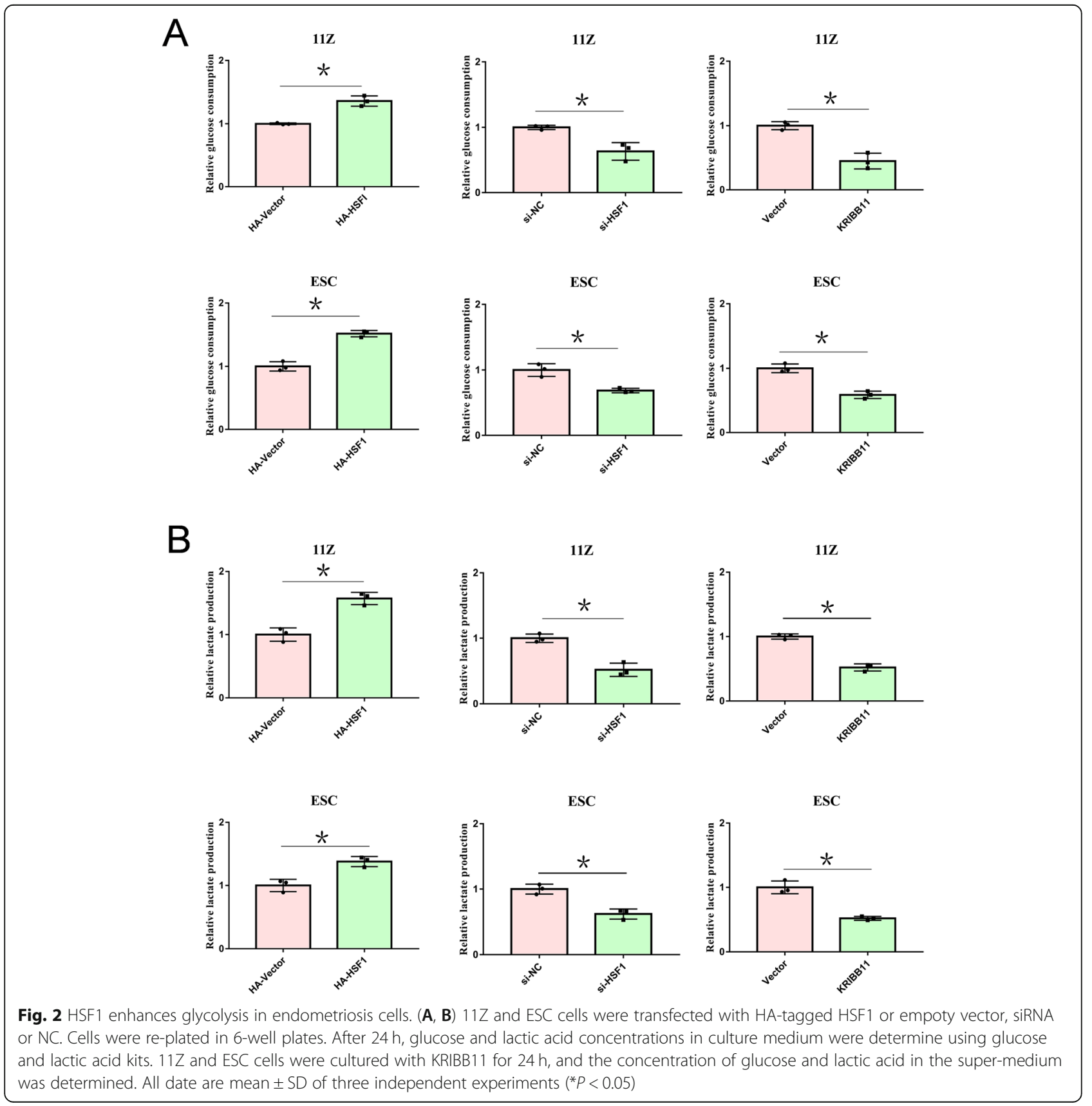




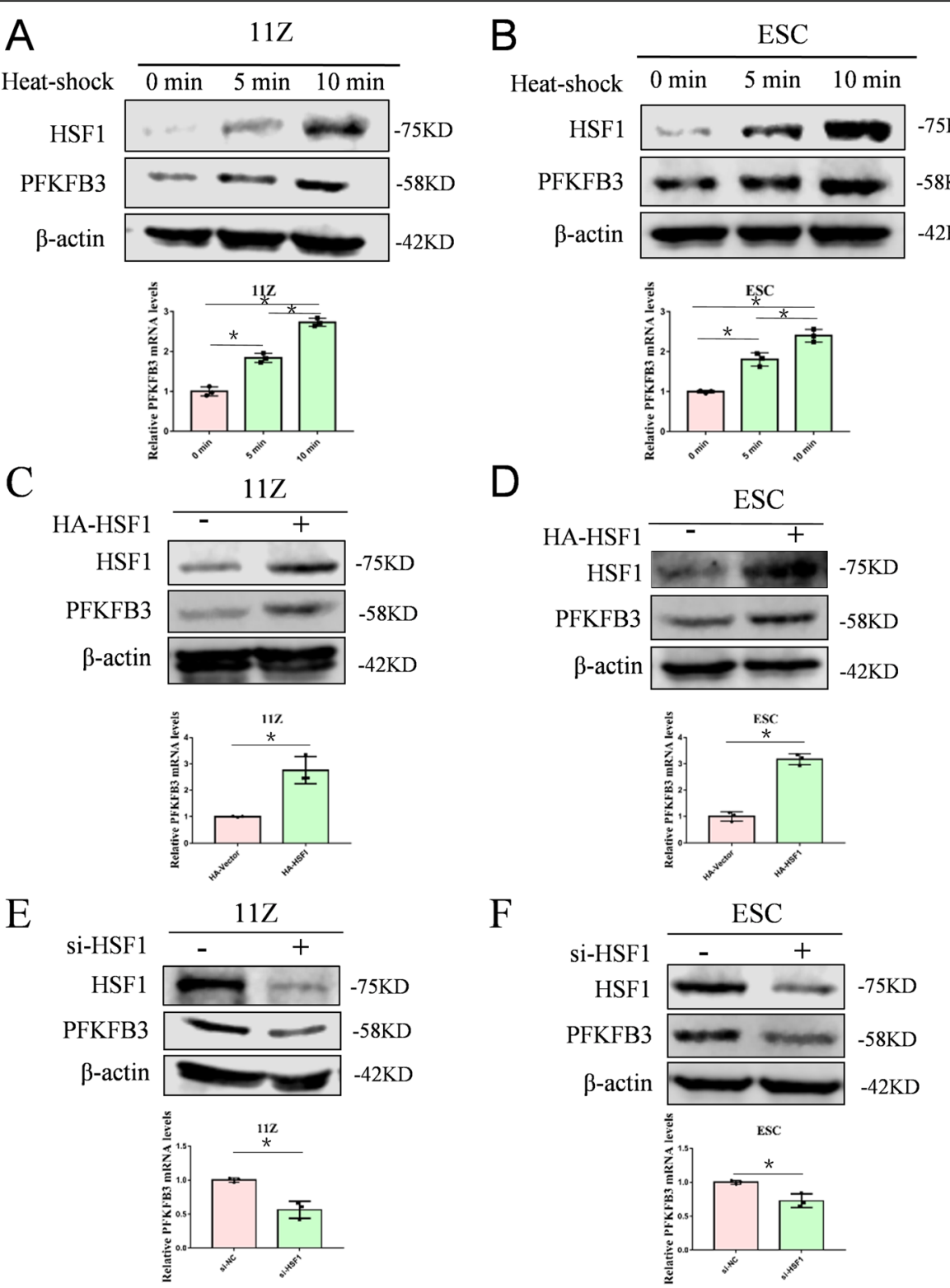

Fig. 3 HSF1 promotes PFKFB3 expression in endometriosis cells. (A, B) 11 Z and ESC cells were heat shocked in a time-dependent manner. The expression of PFKFB3 was determined by Western blot and QRT-PCR. (C, D) 11 Z and ESC cells were transfected with HA-tagged HSF1 or empoty vector, and the expressions of PFKFB3 were detected. (E, F) 11 Z and ESC cells were transfected with siRNA-HSF1 or NC. The expressions of PFKFB3 were detected after 2 days. All date are mean \pm SD of three independent experiments $\left({ }^{*} P<0.05\right)$

given an increasing concentration of KRIBB11. The $\mathrm{IC}_{50}$ values of two cell lines were measured (Fig. 4A). As we expected, KRIBB11 inhibited the growth of endometriosis cells (Fig. 4B and C). Cell-scratch tests indicated that KRIBB11 inhibited the migration of endometrial cells (Fig. 4D). Western blot showed that PFKFB3 protein level was reduced after HSF1 inhibition by KRIBB11 (Fig. 4E). Thus, these data reveal that HSF1-specific inhibitor KRIBB11 reduces the key glycolytic enzyme PFKFB3 expression by inhibiting HSF1, and ultimately inhibits endometriosis cell growth.
KRIBB11 plays a therapeutic role in a mouse model of endometriosis

To determine whether KRIBB11 regulates endometriosis cell growth in vivo, the endometria of donor mice were cut up and intraperitoneally injected into recipient mice. After one week, a mouse model of endometriosis was established, the experimental group was treated with KRIBB11 and the control group was injected with normal saline (Fig. 5A). At the end, the mice were sacrificed to observe ectopic lesion. Interestingly, all control mice were observed the endometriosis tissues, but only two in 


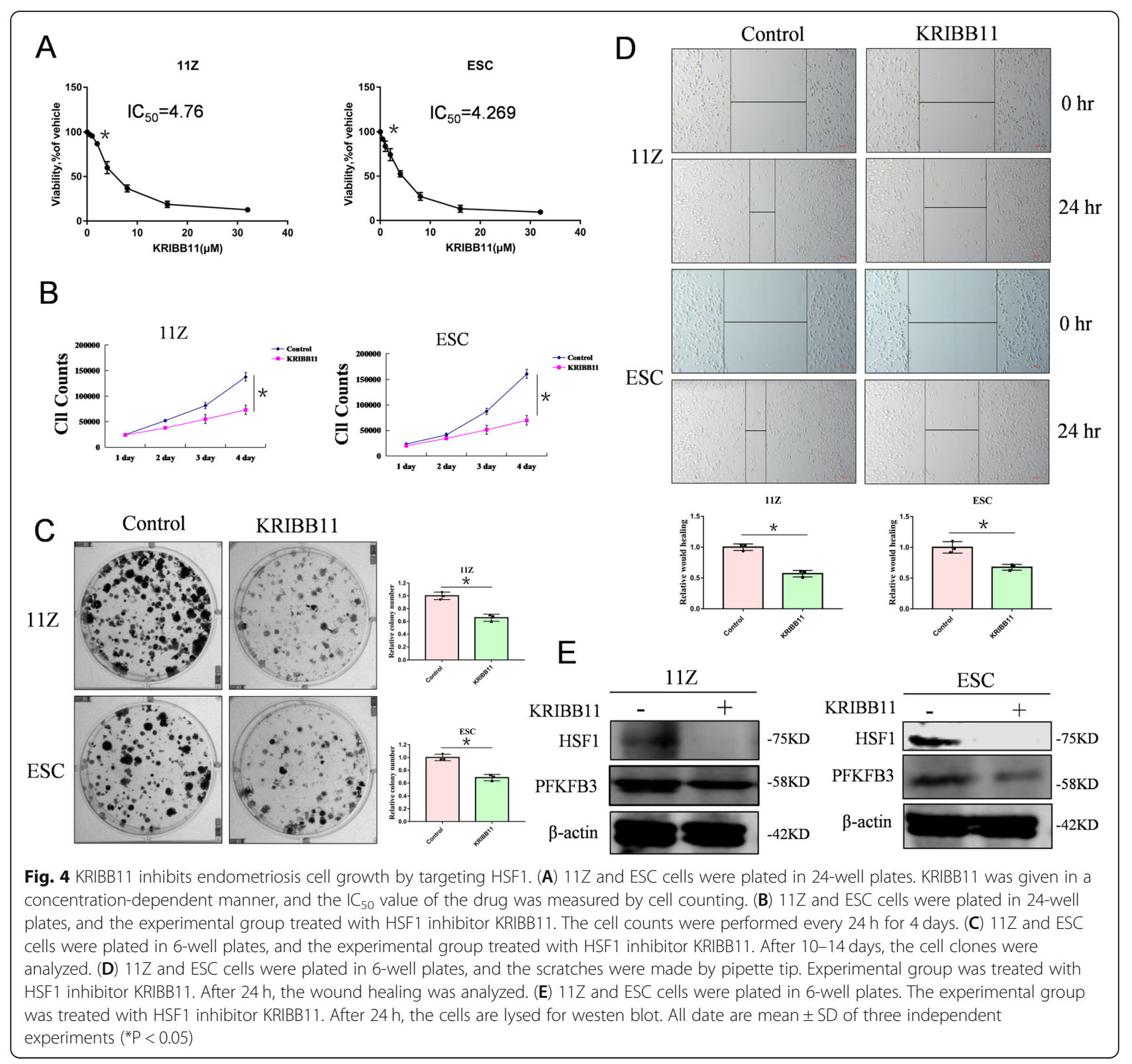

the mice treated with KRIBB11 were observed (Fig. 5B). Ectopic lesions from mice treated with KRIBB11 grew significantly slower than those in control group. Consistently, the weight of ectopic lesions from mice treated with KRIBB11 was lower than in the control group (Fig. 5C). Using immunohistochemical staining, we found that HSF1 expression was significantly lower in the mice treated with KRIBB11 (Fig. 5D). Taken together, HSF1specific inhibitor KRIBB11 plays a therapeutic role in the mouse model of endometriosis.

\section{Discussion}

Endometriosis is an age-related disease of the reproductive system, and its prevalence is up to $10 \%$ in premenopausal women worldwide [6]. The diagnosis of endometriosis is difficult, because experienced obstetricians and gynecologists are required to correctly assess the clinical symptoms of this disease [34]. In recent years, more studies have been published on how to treat endometriosis. However, the treatment of endometriosis is still a clinical challenge, which causes increased burdens to women of childbearing age. Because endometriosis cells have similar characteristics of invasion and metastasis with tumor cells, and HSF1 is a carcinogen promoting tumor progression, so we speculate that HSF1 plays a similar role in the occurrence and development of endometriosis. Our hypothesis is supported by a series of experiments. Our data show that HSF1 promotes endometriosis development, and enhances glycolysis via up-regulating PFKFB3 in endometriosis cells. In mice, we treat with HSF1 inhibitor KRIBB11, 


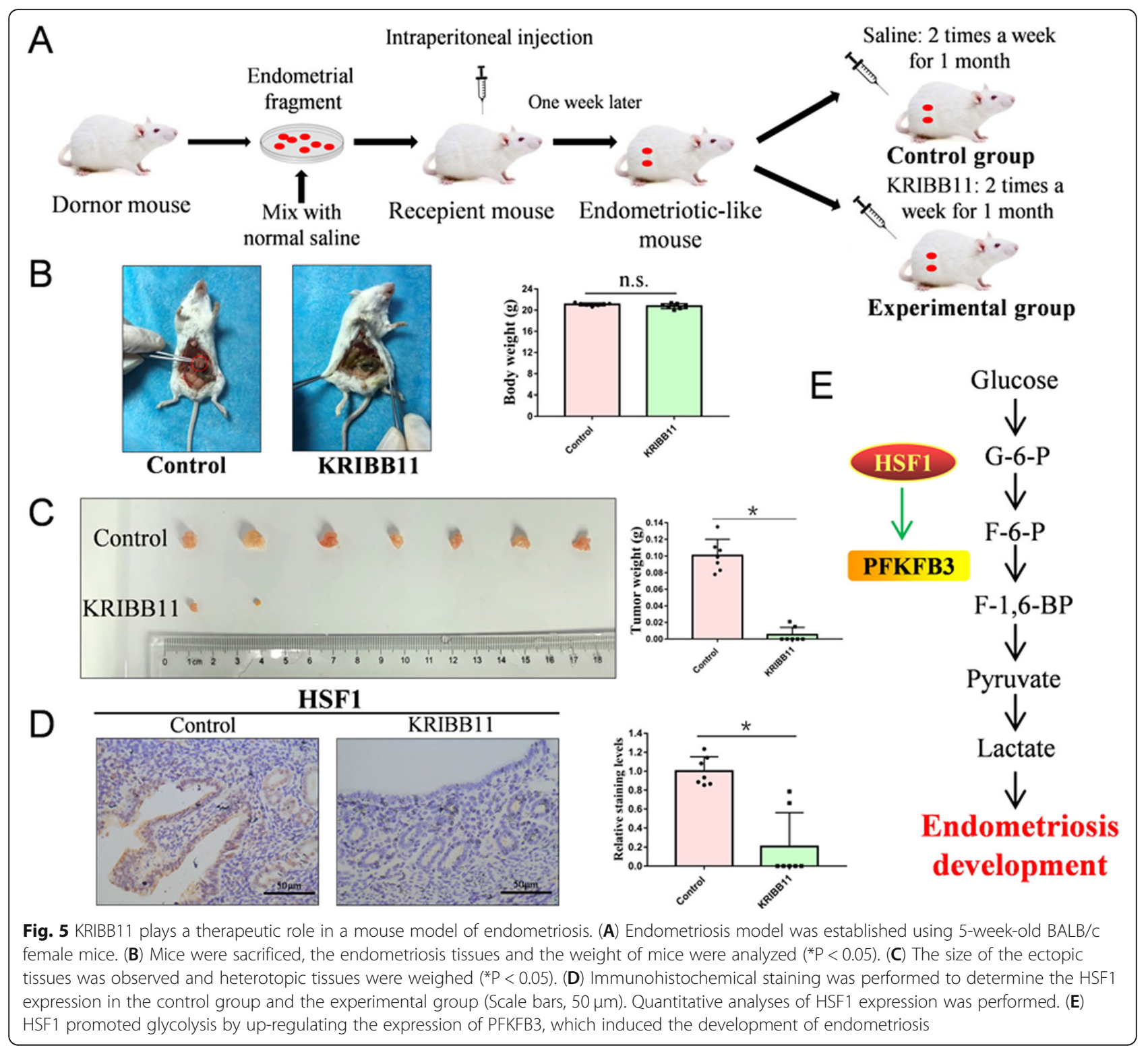

which could effectively inhibit endometriosis development. Taken together, HSF1 is a promising target for endometriosis.

HSF1 is discovered in 1984 as the main regulator of HSR. HSF1 is activated after cell stress, which leads to the HSP expression to protect cells. After heat shock, HSF1 is phosphorylated, trimerized, and transferred to the nucleus to induce chaperone gene expression by binding to DNA sequence motifs known as heat shock elements (HSEs) [35]. HSF1 transcriptional activity mainly depends on the formation of trimer in the nucleus, and post-translational modifications also could regulate its transcriptional activity, such as acetylation, phosphorylation, and methylation [36]. Specially, HSF1 is found to play an important role in multiple cancers, which promotes cell invasion, migration, and proliferation of tumor cells [37]. Cancer cells rely on
HSR to support their rapid growth and counteract the harmful mutations [38]. Previous studies have demonstrated that HSF1 is highly expressed in endometrial carcinoma and is closely related to endometrial invasion, which leads to a poor prognosis in estrogen receptorpositive tumors [39]. Endometriosis is also a highly estrogen-dependent disease [40]. Our study demonstrates that HSF1 plays a crucial role in endometriosis development, which is consistent with previous studies.

Metabonomics can be used as a diagnostic tool to study the metabolic changes under the physiological or pathological state of disease [41]. The lipid metabolism [42], amino acid metabolism [43], and glucose metabolism [13] in patients with endometriosis are increased. Women with endometriosis have high levels of cholesterol compared to a control group without endometriosis [42]. Quantitative 
analysis of lipid metabolites shows that the concentrations of phosphatidylcholine and phosphatidylserine in patients with early endometriosis (I-II) are decreased, while the concentrations of phosphatidylic acid are increased [44]. Endometriosis is largely determined by estrogen synthesis and metabolism genetic factors, which increase the risk of developing endometriosis [45]. Similar to tumor cells, Warburg Effect also occurs in stromal cells of endometrial tissues, which increases glucose consumption and lactate production [13]. In addition, increased glucose metabolism may be the cause of excessive reactive oxygen species in endometriosis [46]. Moreover, the expression of both aerobic and anaerobic glycolytic markers was increased in endometriosis patients, which ultimately contribute to endometriosis development [47]. As a rate-limiting enzyme in glycolysis, PFKFB3 has the highest kinase activity to guide glucose into glycolysis. In our study, we find PFKFB3 is highly expressed and promotes glycolysis in endometriosis cells, which is consistent with previous study that glycolysis promotes endometriosis development. Taken together, our findings provide some new insights into the functions of HSF1/PFKFB3 axis in endometriosis development, which is as a new target to treat endometriosis (Fig. 5E).

\section{Conclusions}

Our data show that HSF1 plays an important role in the development of endometriosis. HSF1 can regulate glycolysis process by up-regulating the expression of PFKFB3 and ultimately promote the growth of endometriosis, while HSF1 specific inhibitors can inhibit the above effects. This will provide a new way of thinking for the treatment of endometriosis in the future.

\section{Abbreviations}

HSF1: Heat shock factor 1; HSR: Heat shock response; HSP: Heat shock protein; HSEs: heat shock elements; PCR: Polymerase chain reaction; qRTPCR: Quantitative real-time PCR; WB: Western blot; PFKFB3: 6-Phosphofructo2-kinase/Fructose-2, 6-Biphosphatase 3; DMEM/F-12: Dulbecco's Modified Eagle Medium/Ham's F-12 50/50 Mix; FBS: Fetal bovine serum; $\mathrm{CO}_{2}$ : Carbon dioxide; RNA: Ribonucleic acid; siRNA: Small interfering RNA; DNA: Deoxyribonucleic acid; CDNA: Complementary DNA; PBS: Phosphate buffer saline; PKM2: pyruvate kinase 2; HK2: Hexokinase 2; $\mathrm{IC}_{50}$ : 50\% inhibiting concentration; $\mathrm{p}$-TEFb: Positive transcription elongation factor $\mathrm{b}$;

SEM: Standard error of the means; SD: Standard deviation; n.s.: Not significant

\section{Supplementary Information}

The online version contains supplementary material available at https://doi. org/10.1186/s12958-021-00770-9.

Additional file 1: Supplementary Figure 1. Heat-shock activation had little effect on the PKM2 and HK2 expressions. (A) $11 Z$ cells were heatshocked for 0 or $10 \mathrm{~min}$, and qRT-PCR was performed to analyze the HK2 and PKM2 mRNA levels. (B) ESC cells were heat-shocked for 0 or $10 \mathrm{~min}$, and qRT-PCR was performed to analyze the HK2 and PKM2 mRNA levels.

Acknowledgments

Not applicable.
Authors' contributions

Z.Y. and C.R. designed research; Z.Y. and Y.W. wrote and revised the paper. All authors read and approved the final manuscript.

\section{Funding}

The study was supported by research grants from National Natural Science Foundation of China (Grant no. 81972489) and National Natural Science Foundation of Shandong Province (Grant no. ZR2020YQ58).

\section{Availability of data and materials}

The data used in this study are available from the corresponding author on reasonable request.

\section{Declarations}

\section{Ethics approval and consent to participate}

All procedures performed in this study involving were in accordance with the ethical standards of the institutional research committee of Weifang medical university.

\section{Consent for publication}

Not applicable.

\section{Competing interests}

The authors declare that they have no competing interests.

Received: 18 December 2020 Accepted: 28 May 2021

Published online: 09 June 2021

\section{References}

1. Mehedintu C, Plotogea MN, Ionescu S, Antonovici M. Endometriosis still a challenge. J Med Life. 2014;7(3):349-57.

2. Giudice LC. Clinical practice. Endometriosis. N Engl J Med. 2010;362(25): 2389-98. https://doi.org/10.1056/NEJMcp1000274.

3. Olsarova K, Mishra GD. Early life factors for endometriosis: a systematic review. Hum Reprod Update. 2020;26(3):412-22. https://doi.org/10.1093/ humupd/dmaa002.

4. Chen $H$, Malentacchi F, Fambrini M, Harrath $A H$, Huang $H$, Petraglia F. Epigenetics of estrogen and progesterone receptors in endometriosis. Reprod Sci. 2020;27(11):1967-74. https://doi.org/10.1007/s43032-020-0022 6-2.

5. Vercellini $P$, Viganò $P$, Somigliana $E$, Fedele L. Endometriosis: pathogenesis and treatment. Nat Rev Endocrinol. 2014;10(5):261-75. https://doi.org/10.103 8/nrendo.2013.255.

6. Wang $Y$, Nicholes $\mathrm{K}$, Shih IM. The origin and pathogenesis of endometriosis. Annu Rev Pathol. 2020;15(1):71-95. https://doi.org/10.1146/annurev-pa thmechdis-012419-032654.

7. Dong B, Jaeger AM, Thiele DJ. Inhibiting heat shock factor 1 in Cancer: a unique therapeutic opportunity. Trends Pharmacol Sci. 2019;40(12):9861005. https://doi.org/10.1016/j.tips.2019.10.008.

8. Kovács D, Sigmond T, Hotzi B, Bohár B, Fazekas D, Deák V, et al. HSF1Base: a comprehensive database of HSF1 (Heat Shock Factor 1) target genes. Int J Mol Sci. 2019;20(22):5815. https://doi.org/10.3390/ijms20225815.

9. Wang G, Cao P, Fan Y, Tan K. Emerging roles of HSF1 in cancer: cellular and molecular episodes. Biochim Biophys Acta Rev Cancer. 1874;2020:188390.

10. Dai C, Sampson SB. HSF1: Guardian of Proteostasis in Cancer. Trends Cell Biol. 2016;26(1):17-28. https://doi.org/10.1016/j.tcb.2015.10.011.

11. Hoang AT, Huang J, Rudra-Ganguly N, Zheng J, Powell WC, Rabindran SK, et al. A novel association between the human heat shock transcription factor 1 (HSF1) and prostate adenocarcinoma. Am J Pathol. 2000;156(3):85764. https://doi.org/10.1016/S0002-9440(10)64954-1.

12. Grunberg N, Levi-Galibov O, Scherz-Shouval R. The role of HSF1 and the chaperone network in the tumor microenvironment. Adv Exp Med Biol. 2020;1243:101-11. https://doi.org/10.1007/978-3-030-40204-4_7.

13. Qi X, Zhang Y, Ji H, Wu X, Wang F, Xie M, et al. Knockdown of prohibitin expression promotes glucose metabolism in eutopic endometrial stromal cells from women with endometriosis. Reprod BioMed Online. 2014;29(6): 761-70. https://doi.org/10.1016/j.rbmo.2014.09.004.

14. Warburg O. On the origin of cancer cells. Science. 1956;123(3191):309-14. https://doi.org/10.1126/science.123.3191.309. 
15. Ghashghaeinia M, Köberle M, Mrowietz U, Bernhardt I. Proliferating tumor cells mimick glucose metabolism of mature human erythrocytes. Cell Cycle. 2019;18(12):1316-34. https://doi.org/10.1080/15384101.2019.1618125.

16. de la Cruz-López KG, Castro-Muñoz LJ, Reyes-Hernández DO, GarcíaCarrancá A, Manzo-Merino J. Lactate in the regulation of tumor microenvironment and therapeutic approaches. Front Oncol. 2019;9:1143. https://doi.org/10.3389/fonc.2019.01143.

17. Kobayashi H, Kimura M, Maruyama S, Nagayasu M, Imanaka S. Revisiting estrogen-dependent signaling pathways in endometriosis: potential targets for non-hormonal therapeutics. Eur J Obstet Gynecol Reprod Biol. 2021;258: 103-10. https://doi.org/10.1016/j.ejogrb.2020.12.044.

18. Shi L, Pan H, Liu Z, Xie J, Han W. Roles of PFKFB3 in cancer. Signal Transduct Target Ther. 2017;2(1):17044. https://doi.org/10.1038/sigtrans.2017.44.

19. Yi M, Ban Y, Tan Y, Xiong W, Li G, Xiang B. 6-Phosphofructo-2-kinase/ fructose-2,6-biphosphatase 3 and 4: a pair of valves for fine-tuning of glucose metabolism in human cancer. Mol Metab. 2019;20:1-13. https:/doi. org/10.1016/j.molmet.2018.11.013.

20. De Bock K, Georgiadou M, Schoors S, Kuchnio A, Wong BW, Cantelmo AR, et al. Role of PFKFB3-driven glycolysis in vessel sprouting. Cell. 2013;154(3): 651-63. https://doi.org/10.1016/j.cell.2013.06.037.

21. Lu C, Qiao P, Sun Y, Ren C, Yu Z. Positive regulation of PFKFB3 by PIM2 promotes glycolysis and paclitaxel resistance in breast cancer. Clin Transl Med. 2021:11:e400.

22. Wang Y, Qu C, Liu T, Wang C. PFKFB3 inhibitors as potential anticancer agents: mechanisms of action, current developments, and structure-activity relationships. Eur J Med Chem. 2020;203:112612. https://doi.org/10.1016/j. ejmech.2020.112612

23. Stephens AN, Hannan NJ, Rainczuk A, Meehan KL, Chen J, Nicholls PK, et al. Post-translational modifications and protein-specific isoforms in endometriosis revealed by 2D DIGE. J Proteome Res. 2010:9(5):2438-49. https://doi.org/10.1021/pr901131p.

24. Gaetje R, Kotzian S, Herrmann G, Baumann R, Starzinski-Powitz A. Nonmalignant epithelial cells, potentially invasive in human endometriosis, lack the tumor suppressor molecule E-cadherin. Am J Pathol. 1997;150(2): 461-7.

25. Krikun G, Mor G, Alvero A, Guller S, Schatz F, Sapi E, et al. A novel immortalized human endometrial stromal cell line with normal progestational response. Endocrinology. 2004;145(5):2291-6. https://doi. org/10.1210/en.2003-1606.

26. Yang T, Ren C, Lu C, Qiao P, Han X, Wang L, et al. Phosphorylation of HSF by PIM2 induces PD-L1 expression and promotes tumor growth in breast Cancer. Cancer Res. 2019;79(20):5233-44. https://doi.org/10.1158/0008-5472. CAN-19-0063.

27. Ren C, Yang T, Qiao P, Wang L, Han X, LV S, et al. PIM2 interacts with tristetraprolin and promotes breast cancer tumorigenesis. Mol Oncol. 2018; 12(5):690-704. https://doi.org/10.1002/1878-0261.12192.

28. Yang T, Ren C, Qiao P, Han X, Wang L, Lv S, et al. PIM2-mediated phosphorylation of hexokinase 2 is critical for tumor growth and paclitaxel resistance in breast cancer. Oncogene. 2018;37(45):5997-6009. https://doi. org/10.1038/s41388-018-0386-X.

29. Lu C, Ren C, Yang T, Sun Y, Qiao P, Wang D, et al. A noncanonical role of Fructose-1, 6-Bisphosphatase 1 is essential for inhibition of Notch1 in breast Cancer. Mol Cancer Res. 2020;18(5):787-96. https://doi.org/10.1158/15417786.MCR-19-0842.

30. Han X, Ren C, Yang T, Qiao P, Wang L, Jiang A, et al. Negative regulation of AMPKalpha1 by PIM2 promotes aerobic glycolysis and tumorigenesis in endometrial cancer. Oncogene. 2019;38(38):6537-49. https://doi.org/10.103 8/s41388-019-0898-z.

31. Lu C, Ren C, Yang T, Sun Y, Qiao P, Han X, et al. Fructose-1, 6bisphosphatase 1 interacts with NF-kappaB p65 to regulate breast tumorigenesis via PIM2 induced phosphorylation. Theranostics. 2020;10(19): 8606-18. https://doi.org/10.7150/thno.46861.

32. Han SJ, Jung SY, Wu SP, Hawkins SM, Park MJ, Kyo S, et al. Estrogen receptor beta modulates apoptosis complexes and the Inflammasome to drive the pathogenesis of endometriosis. Cell. 2015;163(4):960-74. https:// doi.org/10.1016/j.cell.2015.10.034

33. Yoon YJ, Kim JA, Shin KD, Shin DS, Han YM, Lee YJ, et al. KRIBB11 inhibits HSP70 synthesis through inhibition of heat shock factor 1 function by impairing the recruitment of positive transcription elongation factor $b$ to the hsp70 promoter. J Biol Chem. 2011;286(3):1737-47. https://doi.org/10.1 074/jbc.M110.179440.
34. Malvezzi H, Marengo EB, Podgaec S, Piccinato CA. Endometriosis: current challenges in modeling a multifactorial disease of unknown etiology. J Transl Med. 2020;18(1):311. https://doi.org/10.1186/s12967-020-02471-0.

35. Sakurai $H$, Enoki Y. Novel aspects of heat shock factors: DNA recognition, chromatin modulation and gene expression. FEBS J. 2010;277(20):4140-9. https://doi.org/10.1111/j.1742-4658.2010.07829.x.

36. Huang C, Wu J, Xu L, Wang J, Chen Z, Yang R. Regulation of HSF1 protein stabilization: an updated review. Eur J Pharmacol. 2018;822:69-77. https:// doi.org/10.1016/j.ejphar.2018.01.005.

37. Carpenter RL, Gökmen-Polar Y. HSF1 as a Cancer biomarker and therapeutic target. Curr Cancer Drug Targets. 2019;19(7):515-24. https://doi.org/10.21 74/1568009618666181018162117

38. Pincus D. Regulation of Hsf1 and the heat shock response. Adv Exp Med Biol. 2020;1243:41-50. https://doi.org/10.1007/978-3-030-40204-4_3.

39. Engerud H, Tangen IL, Berg A, Kusonmano K, Halle MK, Oyan AM, et al. High level of HSF1 associates with aggressive endometrial carcinoma and suggests potential for HSP90 inhibitors. Br J Cancer. 2014;111(1):78-84. https://doi.org/10.1038/bjc.2014.262.

40. Chantalat E, Valera MC, Vaysse C, Noirrit E, Rusidze M, Weyl A, et al. Estrogen Receptors and Endometriosis. Int J Mol Sci. 2020;21(8):2815. https://doi.org/1 0.3390/ijms21082815.

41. Murgia F, Angioni S, D'Alterio MN, Pirarba S, Noto A, Santoru ML, et al. Metabolic profile of patients with severe endometriosis: a prospective experimental study. Reprod Sci. 2021;28(3):728-35. https://doi.org/10.1007/ s43032-020-00370-9.

42. Melo AS, Rosa-e-Silva JC, Rosa-e-Silva AC, Poli-Neto OB, Ferriani RA, Vieira CS. Unfavorable lipid profile in women with endometriosis. Fertil Steril. 2010;93(7):2433-6. https://doi.org/10.1016/j.fertnstert.2009.08.043.

43. Atkins HM, Bharadwaj MS, O'Brien Cox A, Furdui CM, Appt SE, Caudell DL. Endometrium and endometriosis tissue mitochondrial energy metabolism in a nonhuman primate model. Reprod Biol Endocrinol. 2019;17(1):70. https://doi.org/10.1186/s12958-019-0513-8.

44. Li J, Gao Y, Guan L, Zhang H, Sun J, Gong X, et al. Discovery of phosphatidic acid, phosphatidylcholine, and phosphatidylserine as biomarkers for early diagnosis of endometriosis. Front Physiol. 2018;9:14. https://doi.org/10.3389/ fphys.2018.00014.

45. Wang HS, Wu HM, Cheng BH, Yen CF, Chang PY, Chao A, et al. Functional analyses of endometriosis-related polymorphisms in the estrogen synthesis and metabolism-related genes. PLoS One. 2012;7(11):e47374. https://doi. org/10.1371/journal.pone.0047374.

46. Jana SK, Dutta M, Joshi M, Srivastava S, Chakravarty B, Chaudhury K. 1H NMR based targeted metabolite profiling for understanding the complex relationship connecting oxidative stress with endometriosis. Biomed Res Int. 2013:2013:329058

47. Young VJ, Brown JK, Maybin J, Saunders PT, Duncan WC, Horne AW. Transforming growth factor- $\beta$ induced Warburg-like metabolic reprogramming may underpin the development of peritoneal endometriosis. J Clin Endocrinol Metab. 2014;99(9):3450-9. https://doi.org/1 $0.1210 /$ jc.2014-1026

\section{Publisher's Note}

Springer Nature remains neutral with regard to jurisdictional claims in published maps and institutional affiliations.

Ready to submit your research? Choose BMC and benefit from

- fast, convenient online submission

- thorough peer review by experienced researchers in your field

- rapid publication on acceptance

- support for research data, including large and complex data types

- gold Open Access which fosters wider collaboration and increased citations

- maximum visibility for your research: over $100 \mathrm{M}$ website views per year

At $\mathrm{BMC}$, research is always in progress.

Learn more biomedcentral.com/submissions 